\title{
10
}

\section{Yuki Kihara's Culture for Sale and the History of Pacific Cultural Performance}

\author{
Mandy Treagus
}

One or more dancers in traditional Samoan dress are located on raised platforms; in a darkened adjacent area there is a row of slot machines. The performers, and slot machines, are static unless a viewer interacts with them. In the case of the machines, placing 20 cents in the slot activates a short film loop, featuring one of the performers doing a particular Samoan dance. Similarly, each live performer has a bowl at his or her feet. When a viewer drops money into the bowl, the dancer delivers a short rendering - about 45 seconds - of a dance, each one performing a different traditional form. This is Culture for Sale, a video, installation and performance work, first staged in its full realisation at the Campbelltown Arts Centre for the Sydney Festival in 2012. ${ }^{1}$ It was part of the New Zealand Arts Festival in February 2014 at City Gallery, Wellington, New Zealand, and also featured at Rautenstrauch Joest Museum, Cologne, in January of the same year. Culture for Sale has been explicitly connected by artist Yuki Kihara to the German administration of Samoa and the 'exotic' entertainments provided by

1 Culture for Sale, 2012, short film of the staging of Culture for Sale, dir. Yuki Kihara. It had been staged in performance only, without the slot machines, at the National Gallery of Victoria in 2010 . 
Samoans in German Völkerschau around that period, ${ }^{2}$ during which Samoans functioned as living objects in both performance and onsite villages. ${ }^{3}$ Samoans also featured in other colonial exhibitions, notably the Chicago World's Fair in 1893, at which a group of them, along with other Pacific Islanders, performed and lived. What Kihara evokes so effectively in Culture for Sale is the set of viewing relations and discourses surrounding these original tours, thereby raising wider questions about what happens when culture goes on tour. Viewer pleasure, and potentially discomfort at the contemporary performances cannot be divorced from notions of 'savagery' and 'the primitive' as they circulated in the original colonial tours. The installation also interrogates the distinction between 'the gift' and 'the commodity'; what happens when performances that have been part of 'gift' societies move into capitalist arenas?

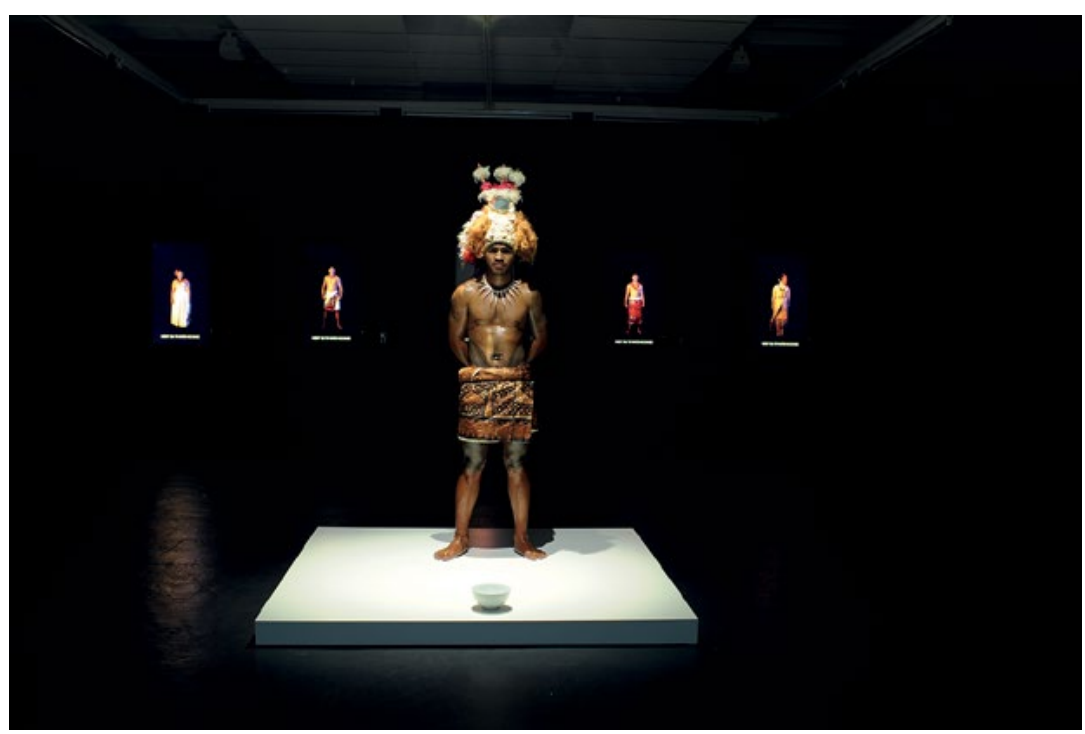

Figure 47. Performer. Ali Korey Vaifale. Culture for Sale. City Gallery, Wellington, 21 February 2014.

Source. Photographed by Sarah Hunter, 21 February 2014, and used with permission.

2 Yuki Kihara and Mandy Treagus, 2014, Forum on Culture for Sale, City Gallery, Wellington, 22 February.

3 Hilke Thode-Arora, 2014, “'Our new fellow countrymen”: The Samoa show of 1900-01', in From Samoa with Love? Samoan Travellers in Germany 1895-1911. Retracing the Footsteps, ed. Hilke Thode-Arora, pp. 117-37, Munich: Museum Fünf Kontinente. 


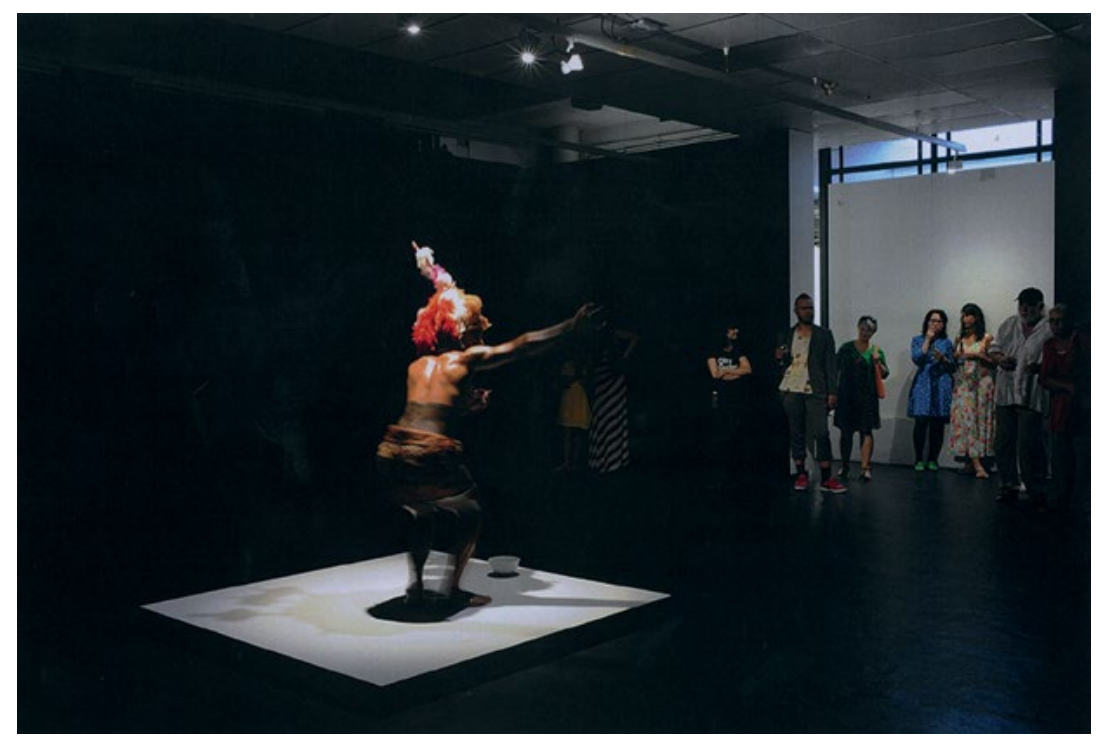

Figure 48. Performer. Ali Korey Vaifale. Culture for Sale. City Gallery, Wellington, 21 February 2014.

Source. Photographed by Sarah Hunter, 21 February 2014, and used with permission.

Should we conceive of the performers who went to Chicago as cultural ambassadors, sharing the culture of their homelands with new audiences, or were they ethnographic objects, on display to illustrate the racial theories of the West and the power of a developing empire that could assemble such curiosities in one place? This is not an idle question, only to be considered in relation to the past. Kihara's work forces us to consider the cost and meaning of contemporary cultural displays in our own time and place. What does it mean to 'sell' culture? Can it be done? Is there always something unequal about the exchange that occurs in cultural performances put on for entertainment? The dances seen in Culture for Sale have a place in traditional life, but up until now that place was not in the gallery. The dances are part of everyday life. Sometimes that place is in formal ceremony; at others it is at events like fundraisers, where dancers are rewarded with money-lafo-for their efforts (and where, significantly, that money is studiously ignored by the performers while in performance). Is there something fundamentally different about dancing to raise funds within a community and dancing for palagi (foreigners) who have paid to be entertained? Cultures are not fixed; they change and indeed they must if they are to continue. But if one's cultural products 
are primarily seen as commercial, does this make them culturally less valuable, and less authentic? And if this is the case, what do we make of the use of cultural performances in the tourist industry? Are some aspects of culture now mainly involved in commercial exchange?

The history of exhibitions and contemporary tourism in the Pacific might seem distant from each other, but in fact they have illuminating links. This chapter seeks to draw out these connections, which are apparent from the early days of the modern phenomena of exhibition practice in the nineteenth century. I specifically explore this relation through the Chicago World's Fair, and consider the ways in which Kihara's Culture for Sale engages with these histories. While challenging the power relations inherent in nineteenth-century tours and celebrating the islander participants who made them possible, Culture for Sale also evokes a range of viewing positions and responses that reproduce such relations. It is this ambivalence that nuances the work and gives it great strength.

While a variety of exhibition forms occurred in Europe over several centuries, including various displays of 'native peoples', modern exhibition culture dates primarily from the Great Exhibition of 1851. As the centre of the largest empire ever seen, London of 1851 set the tone for the multiplicity of Expositions, World's Fairs and Exhibitions that followed over the next century. The tastes of Londoners'an ever unstable mixture, in which an insatiable appetite for novelty contended with a perennial loyalty to staple attractions such as waxworks and freaks ${ }^{4}$ — produced a particular kind of exhibition that always involved entertainment, even when the stated motivations for the Great Exhibition were to demonstrate 'commercial utility, recreation, and instruction'. ${ }^{5}$ The 'curiosity' of Londoners, and the fact that all classes were engaged, ${ }^{6}$ resulted in displays that could be meaningful to the illiterate as well as the educated. Part of this appeal, especially in the ongoing life of the Crystal Palace, was predicated on the perception that its 'exhibits appeared to transcend place and time, to make possible "virtual tourism" to foreign lands

4 Richard Altick, 1978, The Shows of London, Cambridge, Massachusetts: Harvard University Press, p. 3.

5 Alexander Chase-Levinson, 2012, 'Annihilating time and space: Eclecticism and virtual tourism at the Sydenham Crystal Palace', Nineteenth-Century Contexts 34(5): 461-75, p. 462.

$6 \quad$ Altick, The Shows of London, p. 3. 
and distant epochs' ${ }^{7}$ This form of tourism became an inherent part of exhibition planning, execution and appeal. Curtis Hinsley links the gaze employed by those wandering through the Chicago exhibition to the flâneur: "The eyes of the Midway are those of the flâneur, the stroller through the street arcade of human differences, whose experience is not the holistic, integrated ideal of the anthropologist but the segmented, seriatim fleetingness of the modern tourist "just passing through".'8 He goes on to suggest that 'at Chicago in 1893, public curiosity about other peoples, mediated by the terms of the marketplace, produced an early form of touristic consumption ${ }^{\prime 9}$ that was immeasurably enhanced by the presence of 'native' performers and workers.

Following the Great Exhibition, the Paris Exposition of 1889 consolidated the practice of displaying humans as objects of interest in its 'The History of Human Habitation' ${ }^{10}$ These displays became de rigueur in exhibitions over the next 50 years, and were often the most noted features of them. They seemed to offer an experience of parts and peoples of the world not otherwise available before the age of mass tourism. Of the original in Paris, 'The exhibit was in the form of a street of thirty-nine houses, stretching from the Champ de Mars to the Trocadéro, each one representing a culture and a stage in world housing from prehistoric times to the present ${ }^{\prime} .{ }^{11}$ The effect of such displays is well-captured by the French writer Paul Morand, who, as a child, experienced the Paris Exhibition of 1900:

I made a thousand extraordinary journeys almost without moving; under the Eiffel Tower, near the little lake, was hidden the Tonkinese village with its junks and its women chewing betel; sometimes I watched the old Cambodian elephant sent by Doumer and called 'Chérie' drinking there ... The entire hill was nothing but perfumes, incense, vanilla, the aromatic fumes of the seraglio; one could hear the scraping of the Chinese violins, the sounds of the castanets,

\footnotetext{
7 Chase-Levinson, 'Annihilating time and space', p. 463.

8 Curtis Hinsley, 1991, 'The World as marketplace: Commodification of the exotic at the World's Columbian Exposition, Chicago, 1893', in Exhibition Cultures: The Poetics and Politics of Museum Display, ed. Ivan Karp and Steven D. Lavine, pp. 344-65, Washington and London: Smithsonian Institution Press, p. 356.

9 Hinsley, 'The World as marketplace', p. 363.

10 Paul Greenhalgh, 1988, Ephemeral Vistas: The Expositions Universelles, Great Exhibitions

and World's Fair, 1851-1939, Manchester: Manchester University Press, p. 4.

11 Greenhalgh, Ephemeral Vistas, p. 20.
} 
the wailing flutes of the Arab bands, the mystical howling of the Aissawas more heavily painted than De Max, the cries of the Ouled Nail with their mobile bellies; I followed this opiate mixture, this perfume of Javanese dancing girls, sherbets and rahat-lakoum, as far as the Dahomean village. ${ }^{12}$

It was into such realms of curiosity and virtual tourism that the party from Samoa ventured in 1893. Chicago World's Fair was officially named 'The Columbian Exposition' to celebrate the 'discovery' of the Americas by Columbus 400 years earlier, though its lengthy preparations meant that it occurred a year after the actual quadricentenary. It ran over six months, on grounds covering some 250 hectares. ${ }^{13}$ Numerically, one in four Americans saw the Fair, and it was the subject of many features in the press. The Fair was consciously designed to show how much progress the nation had made; it now represented itself as a world leader in technology, industry and knowhow. The fact that the Fair also contained 'native' displays, shops and villages only served to contrast a vision of modernity on the one hand, and a past of 'primitive' stagnation on the other. While some downplayed the importance of 'native' entertainments, the contrast between their apparent frivolity and the serious technological development in the other displays meant that the notion of progress took on a racialised meaning. Human displays provided the contrast needed in order for visitors to fully apprehend how advanced the halls of industry were.

This was enhanced, if anything, by the fact that the large part of the Fair celebrating industry and modern achievements was called the White City. Its name came from the temporary coating on the buildings: staff, 'a mixture of powdered gypsum, alumina, glycerine, and dextrine mixed with fibers to create a plaster' that was effective temporarily but barely lasted the length of the Fair. ${ }^{14}$ Despite its apparently neutral origins, this name persisted in later exhibitions, seeming to serve the

12 Philippe Jullian, 1974, The Triumph of Art Nouveau: Paris Exhibition 1900, London: Phaidon, pp. 158-59.

13 Julian Ralph, 1893, Harper's Chicago and the World's Fair: The Chapters on the Exposition being Collected from Official Sources and Approved by the Department of Publicity and Promotion of the World's Columbian Exposition, New York: Harper and Brothers, p. 235.

14 Judith Adams, 1996, "The American dream actualized: The glistening "white city" and the lurking shadows of the World's Columbian Exhibition', The World's Columbian Exposition: A Centennial Bibliographic Guide, ed. David J. Bertuca, Donald K. Hartman and Susan M. Neumesiter, pp. xix-xxix, Westport: Greenwood, p. xxiii. 
message of progress well, and with it an understanding about race, technology and advancement. Julian Hawthorne, the journalist son of writer Nathaniel, wrote that 'No one pair of eyes can even see it all in six months: as to digesting what you see, that is out of the question. For here are amassed examples of everything that the civilized world produces. ${ }^{15}$ Around 27 million visitors, many from rural USA, came to the Fair via the new railway networks, and they were exposed to inventions that seemed to signal the true advent of Modernity: 'elevators, cash registers, calculating machines, massive search lights, automatic door openers, ironing machines, dishwashers, carpet sweepers, doorbells, phonographs, clocks, industrial motors, an electric dentist's drill, even an electric cigar lighter! ${ }^{16}$ Such displays ushered in modern consumerism, along with promoting the prowess and industrious ingenuity of the nation that produced them. ${ }^{17}$ It also proved to be in marked contrast with the so-called 'primitives and savages' on the Midway. The Ferris Wheel, at 264 feet high, weighing over 45 tons and built of the largest piece of steel thus far forged, ${ }^{18}$ seemed to speak of the Fair's joint industrial and entertainment functions.

This setting, especially its contrast between the modernity of the White City and the 'primitive' nature of the Midway, provided a highly specific lens through which the South Pacific islanders on tour would be viewed by the general public. Culture for Sale also has a very definite frame that evokes specific readings for viewers. Its most distinguishing context is its gallery setting. Not only does this take the performances out of an everyday environment, but it moves them into the arena of fine arts, an unusual one for traditional dance. Who, then, is/are the artist/s here? Is it the performers themselves, whether on film or in the flesh, or is it Kihara, the auteur of the work? Certain factors lead viewers to objectify the performers in similar ways to those in the colonial tours. Performers filmed in the slot machines are inherently objectified; the medium itself offers those portrayed within it to the cinematic gaze of the viewer. Viewers' control of the display via the use of coins enhances this. Similarly, the act of initiating live

15 Julian Hawthorne, 1893, 'The Lady of the Lake (at the Fair)', Lippincott's August: 240-47, p. 241.

16 Adams, 'The American dream actualized', p. xxi.

17 Ibid., p. xx.

18 Ibid., p. xv. 
dances though putting coins in a bowl empowers viewers, but it is the positioning of performers on plinths that invites the most direct objectification. They are inherently placed as statues, static unless activated, and hence under the control of those who gaze at them. Their method of enlistment into the project may not be dissimilar to that of some of the original tourists though, especially those who travelled to the US.

In response to the overtures of Leigh S. Lynch, 'Special Commissioner of the World's Fair for the South Sea Islands', ${ }^{19}$ Harry J. Moors formed a group to perform at the World's Fair. Moors, or Misimoa as he was known to Samoans, was an American businessman who had married Nimo, a Samoan woman, and lived in Apia for almost 20 years, acquiring plantations and businesses. As an American, he also took a very clear position on the civil conflict that gripped Samoa over the final two decades of the nineteenth century, when it was under combined colonial rule. Moors and his previous business partner, William Blacklock, by now the US Consul in Samoa, had had a falling out over the Malietoa-Mata'afa conflict, ${ }^{20}$ and this conflict continued in all their dealings with each other. ${ }^{21}$ Blacklock had officially asked the Samoan Government to provide an exhibit at the Fair but they did not take up the offer, ${ }^{22}$ it was perhaps this failure to initiate a display that antagonised Blacklock when Moors produced his own private arrangement for an exhibit on the Midway. The Samoan press expressed

19 'From the South Sea Islands', 1892, Chicago Daily Tribune, 6 February, p. 12.

20 John Alexander Clinton Gray, 1960, Amerika Samoa: A History of American Samoa and its United States Naval Administration, Annapolis, MD: US Naval Institute, p. 135.

21 While Samoa was not in fact under the sovereign control of a colonial power, it was still largely controlled by the consuls of three nations with interests in the region: Germany, Britain and the United States. This proved to be unworkable: the 'three powers', as they were known in Apia, with their European understandings of royalty and inability or unwillingness to comprehend the Samoan chiefly system, supported one chiefly titleholder as 'king' over the islands. See Malama Meleisea, Penelope Schoeffel Meleisea and Gatoloai Pesta S. Sio, 1987, 'The struggle for monarchy', in Lagaga: A Short History of Western Samoa, ed. Malama Meleisea and Penelope Schoeffel Meleisea, pp. 89-101, Suva: South Pacific Books, p. 99. This was the holder of the Malietoa title of the time. Most Samoans, though, supported the claims of Mata'afa over those of Malietoa. Along with his friend Robert Louis Stevenson, Moors provided both material and moral support to Mata'afa, as the British Consul, Cusack-Smith, complained to Lord Roseberry. See Gerald Horne, 2007, The White Pacific: U.S. Imperialism and Black Slavery in the South Seas after the Civil War, Honolulu: University of Hawai'i Press, p. 218. Stevenson wrote extensively about this conflict and its poor handling by foreign powers, for both The Times of London and in his A Footnote to History. See Robert Louis Stevenson, 1892, A Footnote to History: Eight Years of Trouble in Samoa, London: Cassell.

22 William Blacklock, 1892, Letter to Secretary of State, 8 September, National Archives, USA, Records of the Foreign Service Posts of the Department of State, 84.3. 
doubts about what kind of impression visitors to Moors' exhibit might gain. ${ }^{23}$ Apparently because of Moors' support for Mata'afa, the official ruler, Malietoa, banned Samoans from travelling to Chicago. Blacklock confirms this: 'The real reason why the Government will not allow any Samoans to go with Moors is because of his continued opposition to Malietoa and his Government.' ${ }^{24}$ The government refused to support Moors' group when he publicly requested their help, claiming, with an edge of bitterness, that it would have sent its own group if it had the means. Moors responded in the press by outlining his plan for the Fair:

I have to say that I fear an entirely erroneous idea as to the object of the proposed visit to Chicago and the employment of the people while there seems to have got abroad, and has no doubt somewhat influenced the Government in their decision ... Our people would only be on exhibition in the same way as are the people of China, Japan, Java, Lahore, India, and numerous other places. They will be expected during certain hours of the day to dress in their native way, to paddle canoes, build canoes, cook 'Faa Samoa', and give native songs and dances, sell fans and other things, just in the same way as they will see many other people doing ... It is my object to present in Chicago a perfect picture of Samoan life under favorable circumstances, showing all that is good and attractive and leaving out all that is bad. ${ }^{25}$

Blacklock responded by writing to the captains of the SS Alameda and the SS Mariposa, reminding them of the ban on Samoans travelling overseas without permission, warning them that the Samoan Government 'has reason to believe an attempt will be made to take Samoans away from here to the United States without its consent' and pointing out that Samoans needed a permit to leave the country. ${ }^{26} \mathrm{He}$ also informed the US Assistant Secretary of State of the permit law, and of the fact that no Samoans had been given permission to leave the country for the Fair. ${ }^{27}$ The Samoan Government sent a ship to check one of the steamers, in case anyone joined them at sea. As the Samoa Times reported, a Samoan girl, Tua'a, 'an excellent Siva dancer ... tried to stow away in the Upolu last trip', in order to get to

\footnotetext{
23 Harry J. Moors, 1893, Letter to T. Maben, 1 March, Samoa Weekly Herald, 4 March.

24 Blacklock, Letter to Secretary of State, 8 September.

25 Moors, Letter to T. Maben.

26 William Blacklock, 1893, Letter to Captain Morse, 27 February, National Archives, USA,

Records of the Foreign Service Posts of the Department of State, 84.3.

27 Blacklock, 1892, Letter to Secretary of State, 8 September.
} 
Chicago to join the group. ${ }^{28}$ Later, on the next arrival of the Mariposa into San Francisco, four men and a woman were found who were clearly on their way to Chicago to join the group. Despite denials in Samoa, once the performers had arrived in Chicago, it seemed that a number of them were prepared to admit to being Samoan, given their statements to the press. Other islanders made up the rest of the party, including some from Fiji, Wallis, Rotuma and Tonga, along with afakasi (literally half-castes). Some of these may have been in indenture prior to the trip. Six Samoan women and two small Moors children made up the group. ${ }^{29}$ There were also a number of artefacts for display and sale, including a traditionally made 70 -foot reversible canoe (taumualua). ${ }^{30}$

While it is impossible to say whether all of these travelled voluntarily, is seems clear that many of them did, as indicated by the enthusiasm for the following year's tour to the Mid-Winter Fair in San Francisco. The ship Moors had chartered, the Vine, arrived back in Apia from the Chicago trip on 6 January. On 18 January, a fresh group sailed out to return to Fair life, going via Wallis Island in order to recruit more performers. They had a small adventure while there: at Wallis Island Moors was served with a notice from the French Resident prohibiting him from taking islanders and police were put on the ship to see that the order was obeyed. The ship sailed, the police left, and then three canoes came alongside. When one was swamped, the occupants of the other two - eight persons - were taken on board. They headed for Futuna, followed by a French warship, which had the intention of 'seizing the Vine and arresting her owners'. ${ }^{31}$ Moors was tipped off while on Futuna though, and 'hastened off to his vessel with five Futuna boys. All sail was made, and when the warship came round the island the Vine, which is a capital sailor, was hull down on the horizon.' ${ }^{32}$ While this is something of an adventure tale, it also indicates that many islanders were keen to be part of these tours, and took risks to join them. When Moors was back in Chicago in 1894, he claimed that

28 Samoa Times, 10 June 1893.

29 Honolulu Weekly Bulletin, 11 April 1893, in Samoa Weekly Herald, 20 May 1893.

30 Hubert Howe Bancroft, 1893, The Book of the Fair, Chicago and San Francisco: Bancroft Company, p. 859.

31 Samoa Weekly Herald, 14 April 1894

32 Ibid. 
the group were all 'delighted with their Chicago experience'. ${ }^{33}$ This cannot be said with the same degree of certainty about the German tours, as outlined by Hilke Thode-Arora. ${ }^{34}$

Performers in Culture for Sale, on the other hand, were engaged through expatriate community connections, and their involvement in the performances and filming were personally guided by the artist. Before the opening of the show at City Gallery, Wellington, Kihara personally oversaw preparations by the dancers, both in terms of performance, costume and mental preparedness. She also spent some time debriefing with them after the show, as this proved to be a time of conflicting thoughts and emotions. The effort of standing motionless (when not prompted to dance) and disengaged from viewers appears to have required a different mental approach to that needed for other public performances of traditional dancing. The delicate balance between employing them to highlight the objectification of their ancestors while maintaining their dignity as holders of cultural 'possessions' ${ }^{\prime 35}$ and respected skilled members of their communities needed some negotiation on Kihara's part. At the same time, the critique of objectification that is embodied in Culture for Sale has to be measured with the sense of agency held by many who participated in the original colonial tours.

Human displays in colonial exhibitions developed two dominant kinds of performance: 'staged recreations of cultural performances ... and the drama of the quotidian'. ${ }^{36}$ In its presence on the Midway in Chicago, the South Seas exhibit typified both of these styles. There was a village, built in Samoan style from materials shipped with them, in which stood five traditional fale, including one in the centre 'which stood for ten years in the village of King Mata'afa, and which was sent to the exhibit by him' ${ }^{37}$ The village was open each day, and visitors could see demonstrations of 'mat weaving, fire making

\footnotetext{
33 'Eli liked his trip', 1894, Chicago Daily Tribune, 7 June, p. 9.

34 Hilke Thode-Arora, 2014, “"The belles of Samoa": The Samoa Show of 1895-97', in From Samoa with Love? Samoan Travellers in Germany 1895-1911. Retracing the Footsteps, Munich: Museum Fünf Kontinente, p. 106.

35 Nicholas Thomas, 1999, Possessions: Indigenous Art, Colonial Culture, New York: Thames and Hudson.

36 Barbara Kirshenblatt-Gimblett, 1991, 'Objects of ethnography', in Exhibition Cultures: The Poetics and Politics of Museum Display, ed. Ivan Karp and Steven D. Lavine, pp. 386-443, Washington and London: Smithsonian Institution Press, p. 405.

37 Samoa Weekly Herald, 21 October 1893.
} 
and kava preparation' ${ }^{38}$ Villagers 'played, sang and drank kava' ${ }^{39}$ and gave apparently impromptu musical performances. The verisimilitude of the quotidian was convincing enough to convey a sense that actual Samoan life was being observed in a 'staged authenticity' to use Dean MacCannell's term. ${ }^{40}$ The fact that at 'times, visitors told of seeing the villagers napping in corners of the structure', ${ }^{41}$ only emphasised this. One visitor wrote that 'their manners and customs and ways of living are a source of never-ending wonder to the visitors and they always have attentive audiences whether engaged in making fires by rubbing two sticks together or in making their favorite brew' (presumably 'ava (kava)). ${ }^{42}$ Items of Samoan material culture, including a range of weapons as well as smaller canoes, added to this sense of authenticity. Many of these artefacts from the Fair were bought by the Field Museum when the Fair ended. ${ }^{43}$ Authenticity was a potent form of currency even when its paradoxically constructed nature was acknowledged by all involved.

An incident early in their tour showed both the group's attempts to adapt to US culture, and the steadfast demand by both public and their management that they refuse to do so. When they arrived their hair had reportedly stood out a foot from their heads, in the manner of the day. ${ }^{44}$ Seeing that the locals had short hair, the Samoan men cut their own in an attempt to look the same. They were also wearing western dress, which they were advised to exchange for traditional Samoan garb. ${ }^{45}$ It is likely that they were 'comfortable in both modes of dress' as the performers had attended mission schools. ${ }^{46}$ As they were living onsite until late Fall, wearing scant and light Samoan clothing in order to maintain an aura of 'native' authenticity would have created a real degree of hardship; the islanders were 'anxious to get to a sunnier clime' as the Chicago Daily Tribune reported when they

38 Gertrude M. Scott, 1992, 'Village performance: Villages at the Chicago World's Columbian Exposition 1893', PhD thesis, New York University, p. 273.

39 Scott, 'Village performance', p. 274.

40 Kirshenblatt-Gimblett, 'Objects of ethnography', p. 408.

41 Scott, 'Village performance', p. 272.

42 The Dream City: A Portfolio of Photographic Views of the World's Columbian Exhibition, 1893, St Louis: The World's Columbian Exhibition.

43 Accession File No. 11, Field Museum, Chicago.

44 The Dream City.

45 Wayne quoted in Paige Raibmon, 2005, Authentic Indians: Episodes of Encounter from the Late-Nineteenth Century Northwest Coast, Durham: Duke University Press, p. 223.

46 Scott, 'Village performance', p. 279. 
left on 3 November. ${ }^{47}$ According to press reports, haircutting ceased soon after arrival in the US and 'the Samoans are making a heroic and laudable effort to resume their natural state of barbarism' ${ }^{48}$ This comment indicates that both management and press were aware that 'the primitive' was a construct serving the purposes of the Fair; it was not something intrinsic in itself. And it is perhaps this notion that clings to all cultural performances when they are presented as entertainment. It also invites interrogation about what is being offered. It seems clear that audiences wanted the sense of authenticity however constructed that might be known to be.

The theatre was a more obviously western affair than the village, built as it was for the comfort of audiences and therefore more clearly concerned with entertainment. The shows included dances, songs and chants from the various islands and cultures represented by group members, but it also involved their modification for the theatre environment. The South Seas Theatre was painted by Joe Strong (former stepson-in-law of Robert Louis Stevenson). Julian Hawthorne described it as 'a comfortable little theatre, seating four hundred, with a stage and drop curtain'. ${ }^{49}$ He suggests that he attended it daily, so clearly it held immense appeal for some. Before each show, performers would parade, chanting with a drum in order to attract a crowd, "while the audience waited, and when a sufficient "house" was obtained, the performance would begin'. ${ }^{50}$ War dances were especially thrilling for audiences, and were a large feature of the show, as they were in many others along the Midway. They also suited the environment of the theatre, as they were by 'nature a crafted, stylised exhibition designed precisely for impressing enemies and strangers with what the performers wanted them to see.$^{51}$ and hence could shift from the original cultural setting with little adaptation. Their shows also included paddle dances, sitting dances and the suitably shocking 'cannibal dance', which must have been convincing: 'many of these

47 'Going! Going! Gone!' 1893, Chicago Daily Tribune, 4 November, p. 2.

48 Robert W. Rydell, 1984, All the World's a Fair: Visions of Empire at American International Expositions, 1876-1916, Chicago: Chicago University Press, p. 66.

49 Scott, 'Village performance', p. 271.

50 The Dream City.

51 Jane R. Goodall, 2002, Performance and Evolution in the Age of Darwinism: Out of the Natural Order, London: Routledge, p. 103. 
are but little removed from their period of complete savagery', ${ }^{52}$ an observer reported, without any of the irony of other press reports. A history of cannibalism was often evoked in 'native' performances, and it was a useful marketing tool for attracting audiences, another mark of authentic primitivism. Entry prices were typical for the Midway: the South Sea Island Village was 10 cents and the South Sea Island Theater was 25 cents. $^{53}$

Many commentators rated the village and theatre performances very highly. In The 'Time Saver': A Book which Names and Locates 5,000 things at the World's Fair that Visitors should not fail to see, a Key rates attractions according to the following scale: '1. Interesting, 2. Very Interesting and 3. Remarkably Interesting'. ${ }^{54}$ Most entries, out of 5,000 , are rated at 1 . On the Midway, the 'Samoan village' joins only the Javanese, German, Chinese \& Hagenbeck's Zoological Arena in being rated at $2 .{ }^{55}$ The only attraction to be awarded 3 is the highlight of the Fair, the Ferris Wheel. ${ }^{56}$ Hinsley claims that 'by 1890 two traditions of human display were established: the Hagenbeck-typetour, which occasionally made some claim to ethnographic authenticity and sobriety, and the Barnum-type sideshow of human freaks and oddities. Both were already being incorporated into World's Fairs for the public, and each usually had elements of the other. ${ }^{57}$ Theatre and village manage to incorporate both elements, along with that sense of authenticity, and on the Midway, authenticity lay in evoking the primitive: humanity being experienced in an earlier and more 'natural' state. The constructed nature of this primitivism, and the knowingness with which it was maintained, comes through in both the behaviour of the touring group and in the press reports about them.

When audiences enter the gallery space in which Culture for Sale is being staged, the presence of living performers can seem to breach the conventions around what is appropriate for such spaces (though human participants are increasingly being found in gallery installations).

\footnotetext{
52 The Vanished City: The World's Columbian Exposition in Pen and Picture, n.d., Chicago: Werner.

53 John Flinn, 1893, Official Guide to the Midway Plaisance: The Authorized Official Guide to the World's Columbian Exposition, Chicago: Columbian Guide Company, no. 50.

54 The 'Time Saver': A Book which Names and Locates 5,000 things at the World's Fair that Visitors should not Fail to See, 1893, Chicago: W.E. Hamilton.

55 The 'Time Saver', p. 101.

56 The 'Time Saver'.

57 Hinsley, 'The World as marketplace', p. 346.
} 
Costuming and difference invite a colonial eye, even if one is aware that one is observing a staged version of 'the native', 'the primitive' or even of the 'Samoan'. The sense of engaging with an actual person counteracts, somewhat, the staged authenticity of such interactions. Similarly, and despite ethnographers taking a role in the organising regimes of the Midway, the very presence of living native performers meant that the range of meanings possible for visitors could not be prescribed in the ways they could in the new museums of the time. The possibility that 'exhibits' could step out of their roles as 'primitive' forebears and function as cosmopolitan contemporaries was something that ethnologists at the Fair attempted to limit. When the Samoans cut their hair and wore American clothes, they had the potential to appear as equal correspondents in modernity, entertainers rather than illustrations of Social Darwinism. Though to see the islanders wearing very little enhanced the primitivist illusion, when it became cold in Chicago the touring group was less inclined to play along with the performance and were keen to get into western dress again. Likewise, in Culture for Sale, performers finish their performances, leave their plinths, and return wearing their usual forms of dress, thereby potentially shattering the illusion of their status as human objects.

The apparent message of the Fair-suggested in its division between the White City and the Midway and via its guidebooks - was that humanity existed in lesser and higher forms. This no doubt helped to justify the expansion into the Pacific of US interests, seen in the annexation of the Philippines, Hawai'i and the eastern islands of Samoa. American businessmen secured the deposition of Queen Lili'uokalani in Hawai'i just prior to the Fair, and the US, along with Great Britain and Germany, had controlled Samoa for some time through the condominium arrangement of three consuls largely manipulating the Malietoa. There was, of course, resistance to this, as seen in the outbreak of war while the group was away at the Fair. The fact that the South Sea Islanders concluded their shows by singing 'America' in Samoan must have been reassuring, though it is probable that many Americans knew little about the expansion westward beyond the Pacific coast. ${ }^{58}$ However they might have been described, in both press and guidebooks, the touring group of Samoans and other islanders did not see themselves as illustrations of humanity's savage 
past. It seems much more likely that they saw themselves as working performers at the Fair, travelling, and encountering different cultures and experiences. As Damon Salesa has noted:

The islanders who went with Moors agreed to rigid terms - strict limits on behavior and dress, and work on Sundays - all for $\$ 12$ a month. But Samoans seemed eager to accept those terms for a chance to tafao (wander about) overseas. The Samoans who went with him to San Francisco, Moors promised ... will return to Samoa happy with the strange things they have seen in distant lands, and the things they have brought with them..$^{59}$

Famous travel writer Paul du Chaillu, signing himself simply 'Chaillu', gives an account of a feast given in his honour in the village after Fair hours. It provides some insight into the islanders, and their position in relation to others at the Fair. Before the feast, 'ava (kava) was shared, and the visitor, as a high-status guest, was given the first cup. ${ }^{60}$ This makes it clear that they were welcoming Chaillu as their own guest, not as paid performers in their roles as 'native objects'. The feast was marked by an abundance of food, including a pig, ducks, chicken, fish and other items. ${ }^{61}$ As reported in James Campbell's Illustrated History of the World's Columbian Exposition (1894), when visitors came to the village during work hours, observers noted that they 'tried to give visitors a correct idea of their home life and customs'. ${ }^{62}$ This conveys their sense of themselves as cultural ambassadors, not ethnographic objects. Performers in Culture for Sale, on the other hand, were questioned after their performances as to whether they were representing themselves as objects. After the Campbelltown installation, for example, one dancer described feeling 'claustrophobic' while waiting on the plinth; both being ignored or observed by viewers could induce a sense of diminution by the role and situation. ${ }^{63}$ Another spoke of feeling 'betrayed, exploited, because

59 Damon Salesa, 2005, 'Misimoa: An American on the beach', Common-Place 5(2): n.p.

60 Chaillu, 1893, Samoa Weekly Herald, 30 December.

61 Bancroft, The Book of the Fair, p. 859.

62 James B. Campbell, 1894, Campbell's Illustrated History of the World's Columbian Exposition quoted in Scott, 'Village performance', p. 275.

63 Culture for Sale, 2012, Short film of the staging of Culture for Sale, Dir. Yuki Kihara. 
I had to dance for money' ${ }^{64}$ This is accentuated because performers within the space of the installation have no opportunity to interact with viewers, and because money is the signal to perform. They are inherently objectified, and this is part of the power relations Kihara has evoked in the work. How different this might be from being observed performing the quotidian of village life on the Midway is difficult to say, but the villagers were fundamentally made objects by their status as educational entertainment; both situations produce and reproduce the power relations of colonialism.

Though most often framed through the stereotypes of savagery and cannibalism in the press, the Chicago group was also greatly admired, and praised for their exceptional physiques, especially the men. Casts of both women and men were taken by the Smithsonian as representations of the ideal, ${ }^{65}$ with the stereotype of the 'Noble Savage' clearly at play. Commentators, especially in the press, offered commentary on the bodies of the group, without apparent selfconsciousness. One of these, appearing in the San Francisco Examiner as 'Lady Writer', describes the men enthusiastically: 'great, big strong, muscular fellows, with dark, shining skins and black eyes - [they] dress very scantily indeed'. ${ }^{66}$ Another writer claimed they 'were the best physical specimens of manhood offered by the World's Fair' ${ }^{67}$ The guidebook Midway Types provides a photo caption that reads: A Samoan warrior. A magnificent specimen of the men of the Samoan Village. Their shiny skins, looking like burnished copper, the muscles standing out like ropes, and the quiet manners of these people, made their display one of the most attractive of the Fair. ${ }^{68}$ Midway Types is typical of the many guides and souvenir books that sought to provide racial classifications for any and all of the performers on the Midway.

64 Ibid

65 See Graphics Collection, Chicago History Museum.

66 Lady writer, 1893, Samoa Weekly Herald, 19 August.

67 The Dream City, n.p.

68 Midway Types: A Book of Illustrated Lessons about The People of the Midway PlaisanceWorld's Fair 1893, 1894, Chicago: American Engraving Company, no page. 


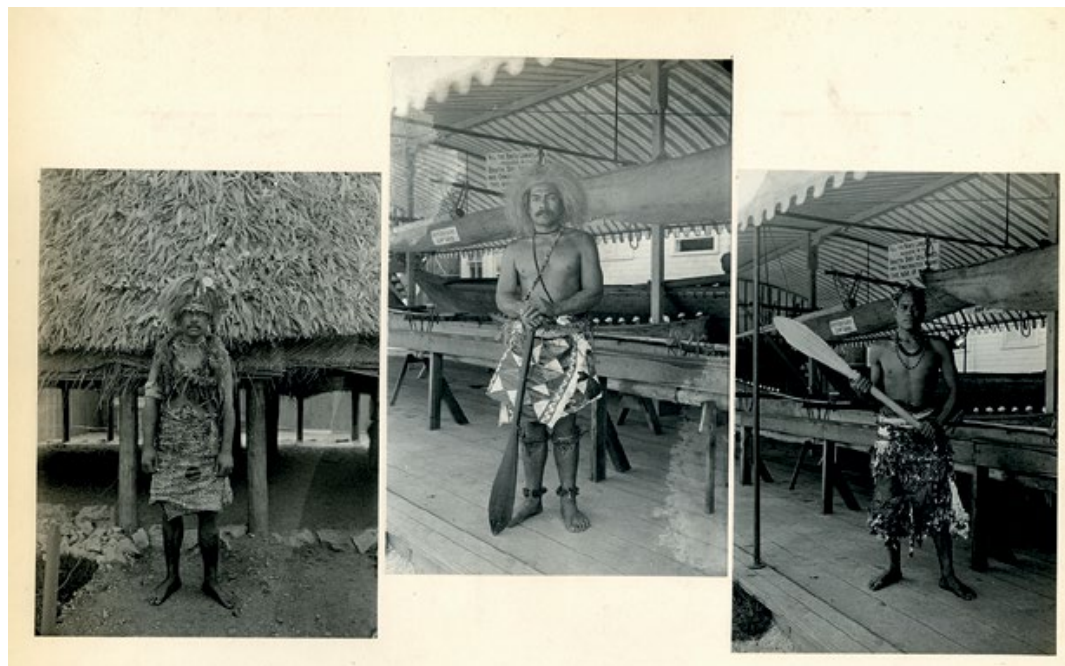

Figure 49. Photographs of men from the Samoan Village taken at the Columbian Exhibition, Chicago, 1893.

Source. Photographed by Thomas Arnold and held in the Chicago Public Library.

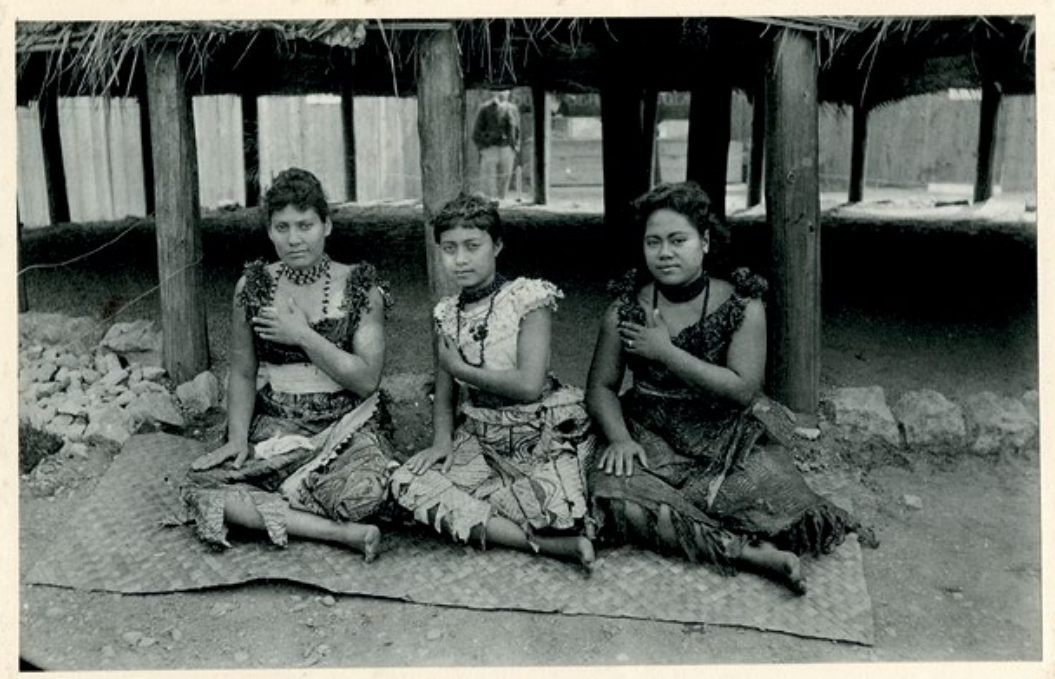

Figure 50. Photograph of women from the Samoan Village taken at the Columbian Exhibition, Chicago, 1893.

Source. Photographed by Thomas Arnold, and held in the Chicago Public Library. 
Similarly, female performers were also eroticised, as in descriptions such as this from the Chicago press: 'Lola, Siva, Fetoai and Mele, the four handsome Samoan girls, whose bare, shining, brown skins, are not among the least attractions of the village. ${ }^{69}$ Mildly erotic photos were taken of them and other women from the Midway. This was, after all, the Fair that popularised the erotic dancing of Little Egypt in the US. One article in the press reported on their attendance of the Fair ball. It is written in an amusing, if patronising, tone and the writer seems pleased with his description of the fashions. In a list of $\mathrm{A}$ to $\mathrm{Z}$ are reports on the various outfits worn:

Fetoai (South Sea Islander) - Costume of bark cloth, skirt cut short, bodice low, ornaments, shells and seed necklace of bright red.

Lola (South Sea Islander) - Native costume of bark cloth covering about half the body, with low cut and sleeveless bodice. Ornaments sea shells, seed bracelets and necklace.

Mele, Miss (Samoan) - One square yard of bark cloth, fringed at the lower edges and held on by a bodice of white muslin cut without sleeves, trimmed with seashells; necklace of grass and weeds; no shoes, no hair ornaments. ${ }^{70}$

The dancers in Culture for Sale are also set apart in the gallery space by their customary dress, including items very similar in description to those listed above, including fine mats, tapa, feathers and tuiga (ceremonial headdresses). These can be read in various ways, as the above press report indicates. The fact that they are still in contemporary use for specific events and celebrations indicates their currency in Samoan life, but it is also possible to read them as items of the exotic other, and hence as an indication of the primitive. Some performers, such as Ali Korey Vaifale in the Wellington Culture for Sale, were also adorned with traditional tattoos, in his case the pe'a. Such body adornments can invite their own specific viewing relations, leading to a further eroticised objectification.

This question of the role of the performers is also raised by Culture for Sale. Viewers can enter the gallery space, and look at the pictures of performers, but involvement is required in order to see a performance. The host of responses the work evokes in the audience is a major

69 Samoa Times, 9 December 1893.

70 'The International Ball at the Fair'. 
part of the way the piece works. Its interactivity means that viewers are not passive in the exchange; they are co-opted into triggering performances and their individual actions in doing this make the exchange much more personal than it would be if they were anonymous members of an audience. The two different parts of the performance evoke a differing range of potential responses. The constant part of the exhibition, the slot machines, provide a much clearer monetary transaction. For each 20 cents, the viewer sees one short film of a dance. The environment, which has been slightly darkened, resonates strongly with overtones of voyeurism. Slot machines only accentuate this, with the specific aesthetics of the peep show coming into play. Despite the fact that the dancers on film are not performing in an erotic manner, the environment in which they are viewed has connotations of erotic performance as part of monetary exchange. This, in turn, has echoes of the original performances in Chicago and Germany, during which a certain amount of sexualised voyeurism was a clear element. Performers were objectified, not just sexually, but also as humans with reduced subjectivity, on display to satisfy racial theories and ethnic curiosity as well as to fulfill preconceived notions of the primitive. These overtones cling to Culture for Sale, and to the slot machine part of the exhibition. More overtly eroticised images were taken the year following Chicago when members of the group attended the Mid-Winter Fair in San Francisco in 1894. These invite an eroticised viewing, with the models posed to evoke the male gaze, even though they were not seen in performance wearing so little or in such poses. Even without an erotic element such as was present in representations of nineteenth-century performers, the slot machine aspect of the piece is empowering to viewers, who remain in control.

This does not shut down other meanings of the slot machines; the skill, balance and beauty of the dancing is significant, and it is also seen in the live performances, which evoke a new set of interactions and power relations. Observing a dancer becoming tired and sore, especially in the case of the slap dance, is a very close and personal experience for viewers, and makes the power relations very stark. Throw money in the bowl, make the dancer dance. The sounds of coins in a china bowl is a strong reminder of the economics of what is occurring; it cannot, however, wholly account for the viewer's response to the dancer's skill, nor does it necessarily contain the dancer's participation in traditional dance. 


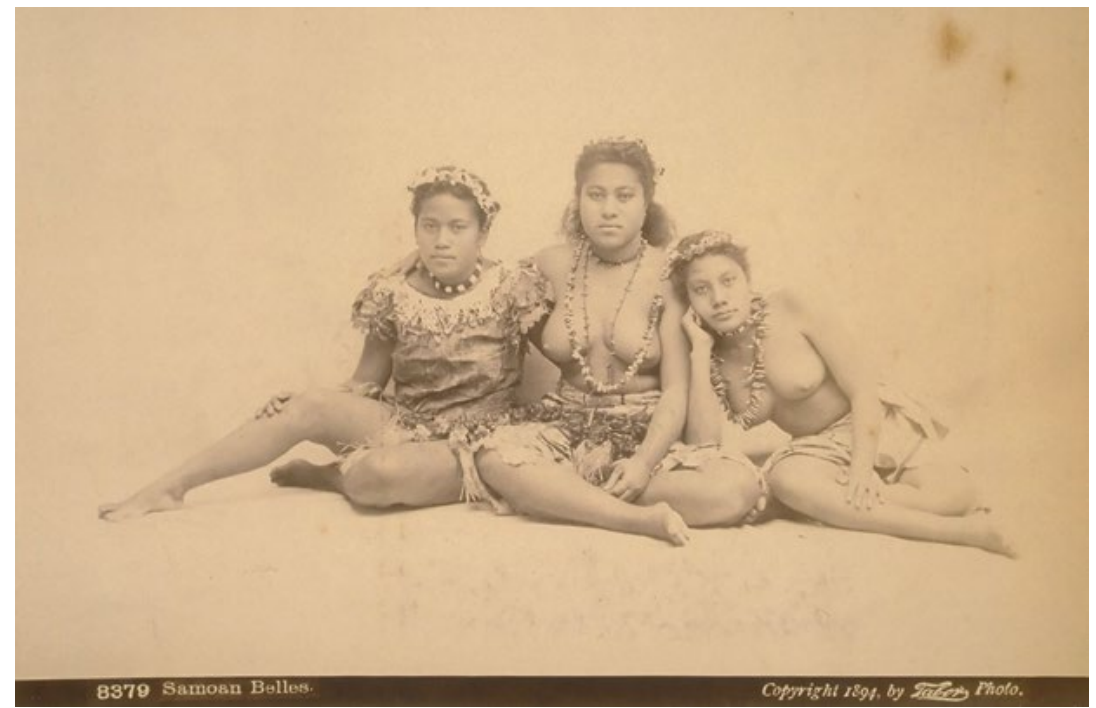

Figure 51. 'Samoan Belles'. Mid-Winter Fair, San Francisco, 1894.

Source. Courtesy of The Bancroft Library, University of California, Berkeley. Call number: 10015235.

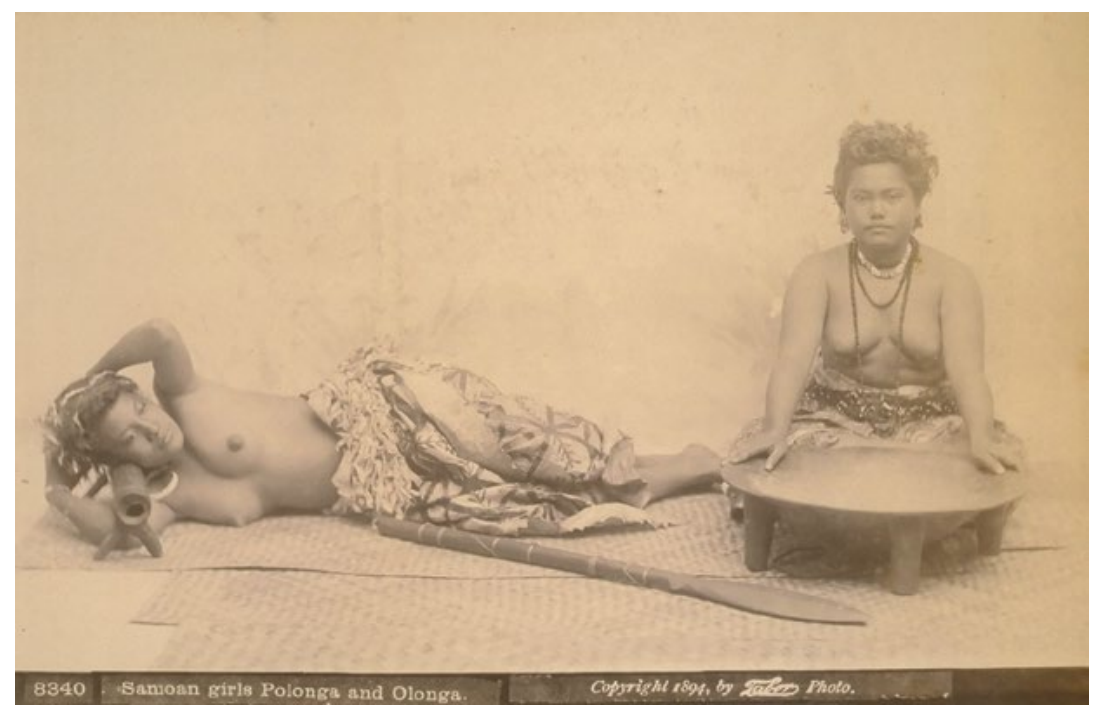

Figure 52. 'Samoan Girls Polonga and Olonga'. Mid-Winter Fair, San Francisco, 1894.

Source. Courtesy of The Bancroft Library, University of California, Berkeley. Call number: 10015232. 
I return to the questions posed early in this chapter. Culture for Sale not only critiques and draws attention to the nineteenth-century tours it speaks back to, but it also questions the power relations inherent in contemporary tourism. It asks whether any exchange of cultural performance for money shifts the meaning of that cultural possession from gift to commodity, thereby abandoning the 'reciprocal dependence and inalienability' of that gift by taking it out of its original culture and placing it in a western market system. ${ }^{71}$ It also complicates the binary, which sees cultural possessions such as dances as 'inalienable' gifts, by forcing viewers to engage with them as 'commodities'. ${ }^{72}$ In addition to this, as Teresia Teaiwa asked during a Culture for Sale forum, is Kihara functioning as a modern-day Mr Moors, perpetuating the same set of relations as existed in colonial exhibitions? $?^{73}$ Viewers of the installation and performance are forced to examine their own relations with performers when they 'buy' culture in this way, and Kihara deliberately skates close to reinforcing the viewing relations of colonialism in staging this work. The provocation of riding this knife edge between colonising and decolonising discourses makes Culture for Sale powerful, disturbing and arresting, both as a piece that allows for the unpredictability of performance and interaction, and as one that simultaneously evokes the power relations it seeks to critique.

\section{References}

\section{Archival repositories}

Chicago Field Museum.

Chicago History Museum, Graphics Collection.

National Archives, USA, Records of the Foreign Service Posts of the Department of State.

71 Chris A. Gregory, 1982, Gifts and Commodities, New York: Academic Press, p. 24.

72 Nicholas Thomas, 1991, Entangled Objects: Exchange, Material Culture, and Colonialism in the Pacific, Cambridge MA: Harvard University Press, p. 15.

73 Kihara and Treagus, forum on Culture for Sale. 


\section{Books, articles and chapters}

Adams, Judith A. 1996. "The American dream actualized: The Glistening "white city" and the lurking shadows of the World's Columbian Exhibition.' In The World's Columbian Exposition: a Centennial Bibliographic Guide, ed. David J. Bertuca, Donald K. Hartman and Susan M. Neumesiter, pp. xix-xxix. Westport: Greenwood.

Altick, Richard. 1978. The Shows of London. Cambridge, Massachusetts: Harvard University Press.

Bancroft, Hubert Howe. 1893. The Book of the Fair. Chicago and San Francisco: Bancroft Company.

Blacklock, William. 1892. Letter to Secretary of State. 8 September.

National Archives, USA, Records of the Foreign Service Posts of the Department of State, 84.3.

_ 1893. Letter to Captain Morse. 27 February. National Archives, USA, Records of the Foreign Service Posts of the Department of State, 84.3.

Chase-Levinson, Alexander. 2012. 'Annihilating time and space: Eclecticism and virtual tourism at the Sydenham Crystal Palace.' Nineteenth-Century Contexts 34(5): 461-75.

Culture for Sale. 2012. Short film of the staging of Culture for Sale. Dir. Yuki Kihara.

Flinn, John. 1893. Official Guide to the Midway Plaisance: The Authorized Official Guide to the World's Columbian Exposition. Chicago: Columbian Guide Company.

Goodall, Jane R. 2002. Performance and Evolution in the Age of Darwinism: Out of the Natural Order. London: Routledge.

Gray, John Alexander Clinton. 1960. Amerika Samoa: A History of American Samoa and its United States Naval Administration. Annapolis, MD: US Naval Institute.

Greenhalgh, Paul. 1988. Ephemeral Vistas: The Expositions Universelles, Great Exhibitions and World's Fair, 1851-1939. Manchester: Manchester University Press. 
Gregory, Chris A. 1982. Gifts and Commodities, New York: Academic Press.

Hawthorne, Julian. 1893. 'The Lady of the Lake (at the Fair).' Lippincott's August: 240-47.

Hinsley, Curtis. 1991. 'The World as marketplace: Commodification of the exotic at the World's Columbian Exposition, Chicago, 1893.' In Exhibition Cultures: The Poetics and Politics of Museum Display, ed. Ivan Karp and Steven D. Lavine, pp. 344-65. Washington and London: Smithsonian Institution Press.

Horne, Gerald. 2007. The White Pacific: U.S. Imperialism and Black Slavery in the South Seas after the Civil War. Honolulu: University of Hawai'i Press.

Jullian, Philippe. 1974. The Triumph of Art Nouveau: Paris Exhibition 1900. London: Phaidon.

Karp, Ivan and Steven D. Lavine (eds). 1991. Exhibition Cultures: The Poetics and Politics of Museum Display. Washington and London: Smithsonian Institution Press.

Kihara, Yuki, 2012-15. Culture for Sale. Installation, performance and video work.

Kihara, Yuki and Mandy Treagus. 2014. Forum on Culture for Sale. City Gallery, Wellington, 22 February.

Kirshenblatt-Gimblett, Barbara. 1991. 'Objects of ethnography.' In Exhibition Cultures: The Poetics and Politics of Museum Display, ed. Ivan Karp and Steven D. Lavine, pp. 386-443. Washington and London: Smithsonian Institution Press.

Meleisea Malama and Penelope Schoeffel Meleisea (eds). 1987. Lagaga: A Short History of Western Samoa. Suva: South Pacific Books.

Meleisea Malama, Penelope Schoeffel Meleisea and Gatoloai Pesta S. Sio. 1987. 'The struggle for monarchy.' In Lagaga: A Short History of Western Samoa, ed. Malama Meleisea and Penelope Schoeffel Meleisea, pp. 89-101. Suva: South Pacific Books. 
Midway Types: A Book of Illustrated Lessons about The People of the Midway Plaisance - World's Fair 1893. 1894. Chicago: American Engraving Company.

Raibmon, Paige. 2005. Authentic Indians: Episodes of Encounter from the Late-Nineteenth Century Northwest Coast. Durham: Duke University Press.

Ralph, Julian. 1893. Harper's Chicago and the World's Fair: The Chapters on the Exposition being collected from Official Sources and Approved by the Department of Publicity and Promotion of the World's Columbian Exposition. New York: Harper and Brothers.

Rydell, Robert W. 1984. All the World's a Fair: Visions of Empire at American International Expositions, 1876-1916. Chicago: Chicago University Press.

Salesa, Damon. 2005. 'Misimoa: An American on the beach.' CommonPlace 5(2): n.p.

Scott, Gertrude M. 1992. 'Village performance: Villages at the Chicago World's Columbian Exposition 1893.' PhD thesis. New York University.

Stevenson, Robert Louis. 1892. A Footnote to History: Eight Years of Trouble in Samoa. London: Cassell.

The Dream City: A Portfolio of Photographic Views of the World's Columbian Exhibition. 1893. St Louis: The World's Columbian Exhibition.

The 'Time Saver': A Book which Names and Locates 5,000 things at the World's Fair that Visitors should not Fail to See. 1893. Chicago: W.E. Hamilton.

The Vanished City: The World's Columbian Exposition in Pen and Picture (n.d.). Chicago: Werner.

Thode-Arora, Hilke, 2014. "The Belles of Samoa": The Samoa Show of 1895-97.' In From Samoa with Love? Samoan Travellers in Germany 1895-1911. Retracing the Footsteps, ed. Hilke ThodeArora, pp. 93-116. Munich: Museum Fünf Kontinente. 
2014. "'Our new fellow countrymen": The Samoa show of 1900-01.' In From Samoa with Love? Samoan Travellers in Germany 1895-1911. Retracing the Footsteps, ed. Hilke Thode-Arora, pp. 117-37. Munich: Museum Fünf Kontinente.

Thode-Arora, Hilke (ed.). 2014. From Samoa with Love? Samoan Travellers in Germany 1895-1911. Retracing the Footsteps. Munich: Museum Fünf Kontinente.

Thomas, Nicholas. 1991. Entangled Objects: Exchange, Material Culture, and Colonialism in the Pacific. Cambridge MA: Harvard University Press.

Thomas, Nicholas. 1999. Possessions: Indigenous Art, Colonial Culture. New York: Thames and Hudson.

\section{Newspapers}

Chicago Daily Tribune

Honolulu Weekly Bulletin

Samoa Times

Samoa Weekly Herald

Samoa Weekly Herald

San Francisco Examiner 
This text is taken from Touring Pacific Cultures, edited by Kalissa Alexeyeff and John Taylor, published 2016 by ANU Press, The Australian National University, Canberra, Australia. 